International Journal of Child, Youth and Family Studies (2020) 11(2): 61-81

DOI: $10.18357 /$ ijcyfs112202019519

\title{
QUEERING CHILD AND YOUTH CARE
}

\section{Wolfgang Vachon}

\begin{abstract}
Building on queer theory, on formative and current discourses of child and youth care (CYC), and on feminist and other ethics of care theorizing, this paper applies queer analytics to CYC by considering how desire, identity, sexuality, theory, and politics may be taken up within CYC.
\end{abstract}

Keywords: care, queer theory, child and youth care, LGBTQI2SA

Wolfgang Vachon is a Professor in the School of Social and Community Services, Humber Institute of Technology and Advanced Learning, 3199 Lakeshore Blvd. W., Toronto, Ontario, Canada M8V 1K8. Email: Wolfgang.Vachon@,Humber.ca 
International Journal of Child, Youth and Family Studies (2020) 11(2): 61-81

\section{Caring for the Land}

In considering care, I start by recognizing the many peoples who have lived on and cared for the land upon which this paper was conceived, presented, edited, and where it will be read - land which has been home to many species and materials over hundreds of millions of years. This paper was originally presented on the territories of the Lekwungen-speaking, Songhees, Esquimalt, and WSÁNEĆ peoples. I live and work on the traditional lands of the Huron-Wendat and Petun First Nations, the Anishinaabe, the Six Nations of the Haudenosaunee, and the Mississaugas of the Credit First Nation. It is likely that the reader of this paper also lives in a region that has a history of migration, settlement, war, colonization, and displacement. As I edit this draft, I am in eThekwini, the Zulu name for the area that was colonized most recently from the Zulu and renamed Durban, South Africa — land inhabited by hunter-gatherers for at least 100,000 years.

The Toronto region, where I live, was bought in 1805 by the British Crown from the Mississaugas of the Credit under the terms of the Toronto Purchase Treaty, also called Treaty 13 (Mississaugas of the Credit First Nation, n.d.). However, this treaty was not finally settled until 2010. The revised settlement (from the original purchase price of 10 shillings, the equivalent of about $\$ 27$, to a settlement claim of $\$ 145$ million) was due to the perseverance of the Mississaugas of the Credit First Nation, who contested the documents upon which Treaty 13 was based (Mississaugas of the Credit First Nation, n.d.). Treaty 13, as originally implemented, has been described as less like a treaty than a theft based on dubious documents and colonialist mapping (Simpson, 2008).

In addition to deception through administrative dishonesty, the EuroCanadian view of treaties, according to Simpson (2008), does not recognize that, "First and foremost, treaties are about maintaining peace through healthy collective relationships" (p. 35). Healthy collective relationships have infrequently, if ever, been the intention of British, French, and Canadian governments when establishing institutional relationships with Indigenous peoples, and this has significant implications for child and youth care (CYC).

Most land acknowledgements done in Toronto recognize that the land is also part of Dish With One Spoon, a treaty between First Nations. Simpson (2008) calls upon settlers to honour the intentions of Dish With One Spoon, recognizing that we all share the same resources, we are all responsible for taking care of the territory, and we will not interfere with one another's sovereignty. There should be no weapons present, only spoons, as we meet and commit to living in harmony with the land and with each other. It is worth considering how well the field of CYC and its practitioners have followed the intentions of Dish With One Spoon, both historically and currently. Part of the history of CYC is a history of colonialization, regulation, and disenfranchisement (Beukes \& Gannon, 1999; Charles \& Gabor, 2006; de Finney et al., 2018). 
International Journal of Child, Youth and Family Studies (2020) 11(2): 61-81

Many within CYC navigate this complex reality regularly in our work with young people, in our negotiations with professors, when teaching students, and while doing research. This is true across locations, whether one is White, cis-gendered, middle-aged, male, or otherwise privileged, like myself, or — like many CYC practitioners (CYCPs) — racialized, Indigenous, marginalized, minoritized, young, female, or otherwise lacking the multiple benefits of privilege. As I try to move beyond the preliminary step of acknowledging land towards understanding the implications of my presence on the land, and the responsibilities thus entailed, I have taken the opportunity to think, speak, and ask for feedback about my own land acknowledgements. After the workshop that gave rise to this paper, I asked for feedback regarding how I acknowledged the land and its keepers. I was told that I did not put myself into the acknowledgment.

I agree.

When reflecting upon the theory of care and our practice as CYCPs, it is instructive to consider how one brings one's self to one's work. When doing research, locating one's position and subjectivity can reveal insights into how one understands what one is studying. This, I am coming to recognize, is also true of land acknowledgments. Land acknowledgements invite me to consider how my own actions perpetuate settler-colonialist-occupier positions, thinking, and practices. Every time I do a land acknowledgment, I am called to study how I am implicated through my presence and actions.

The Truth and Reconciliation Commission (TRC) of Canada (2015) looked at the residential school system that existed in Canada for over 100 years. The final report delivers 94 calls to action in a number of areas, including child welfare, education, and programs for justice, health, and youth. As a CYC practitioner who also teaches in post-secondary education, I am implicated in all of these calls. I am also implicated as a White settler-occupier and as a man in the 231 calls for justice contained in Canada's recent National Inquiry into Missing and Murdered Indigenous Women and Girls (2019). Beyond the specific, clear, and direct calls to action in each of these documents, I hear another call, a call to each of us who lives on colonized land: a call to care.

\section{Queer Theory}

Care permeates queerness. It can be seen in the careful ways that sex, identity, desire, and love must be traversed in queer life throughout history and to this day in many countries, communities, and families; in the care-filled ways that queer people (male, female, trans, others) came together to look after one another when HIV/AIDS first ravaged the gay community, and as it continues to infect around the world; in the caring ways that communities of queers have formed throughout history when rejected by family, friends, employers, and society; in the many diverse, creative, and taboo acts of sexual expression that queering desire gives rise to (although, this is certainly not exclusive to lesbian, gay, or trans people); and in the navigation of homophobic policies, practices, and people. Queerness requires and radiates care in our desires, sexuality, identity, politics, and theory. It is within these five elements of queerness that I centre this paper as it relates to CYC practice. 
International Journal of Child, Youth and Family Studies (2020) 11(2): 61-81

Shotwell (2016), in her book Against Purity, rejected urgent imperatives and suggested "shifting from categorical imperatives to hypothetical imperatives" (p. 8). Instead of the categorical "we need", or "we must", she suggested changing our stance to "if we". The "if" opens up possibilities, creating space and opportunities. This is, at least partially, what CYC is about possibilities, creating spaces, and finding opportunities. In this "if", I embrace the call for queer worldmaking from the likes of Muñoz (2009) and Alexander (2018).

Muñoz (2009) called for a revivification of the queer political imagination. I invite readers to consider a queer CYC imagination, one that recognizes, perhaps even celebrates, desire, sex, identity, theory, and politics. And to wonder, together, what this might mean — what does queering CYC do?

Ball (2016) asserted that queer theory actively works against a reduction to its essence. And yet, it is useful to have a construct to contest. Alexander (2018) located queer theory as coming out of critical social theory, stating that it "is engaged in an active process of contesting scholarship and politics, contesting categories, contesting identity, contesting liberalism, contesting truth, contesting history, and contesting subjectivity" (p. 278). While all this contestation might seem overly oppositional, queer theory also moves towards "expounding, elaborating, and promoting alternative ways of being, knowing, and narrating experience" (Alexander, 2018, p. 278), which is something many CYCPs seek to do in their practice. As part of this move, Alexander (2018), building on the work of Johnson (2001) — both authors are Black gay men — uses "quare" theory to disrupt the Whiteness that has historically dominated queer theory. (Johnson explained that he uses "quare" because that is how his Southern grandmother pronounced "queer".)

I see queer theory existing in two primary ways (the irony of binary reductionism is intentional). In one manifestation, queer theory critically analyzes issues facing lesbian, gay, bisexual, trans, queer (questioning), intersex, two-spirit, and asexual people (LGBTQI2SA). This analysis tends to be identity- and problem-focused. Abramovich and Shelton (2017) provide such an analysis in their useful book that looks at homelessness and the LGBTQ2S community:

Understanding the societal oppression of LGBTQ2S people through the lenses of cissexism and heterosexism allows us to broaden the analysis of the harassment and discrimination faced by LGBTQ2S youth experiencing homelessness from looking only at the micro-level of interpersonal interactions to include the macro level of institutional structures that produce and maintain this group's marginalization.... This understanding directs our attention to the ways our systems have failed LGBTQ2S youth and calls us to redesign our systems to meet the needs of all youth. (pp. 338-339)

In this quote, we see several elements of identity and issue-focused queer theory: classification of the specific population, naming of debilitating factors, critiques of systemic oppression, and calls for concrete actions towards addressing the recognized problems. While there is a focus on 
International Journal of Child, Youth and Family Studies (2020) 11(2): 61-81

LGBTQ2S people, Abramovich and Shelton's (2017) analysis is couched in language that points out how all are advantaged when change is made, an approach not dissimilar to universal design in disability studies.

This approach is familiar, and comfortable, to many CYC practitioners. Most writing that might be affiliated with queer theory in CYC analyzes, evaluates, designs, or supports programs and services that cater to LGBTQI2SA children and youth, while at times justifying these programs through arguing the benefits for all. Much of the writing falls into a particular homonormative discourse regarding only LGT people, and thus might not be considered queer, in a critical theory sense, at all.

The second mode of queer theory is seen in the application of a queer analytic to topics that may not necessarily be understood as queer. Through this "queering", there is an attempt to look at, understand, and reveal existing binaries, norms, and systems in order to show how these function. As Ball (2016) writes, "queering something involves a deconstructive disposition that points to norms, resists them, and opens up a space in which things might be done differently" (p. $35)$.

While much of this critique is done in spaces not exclusively gay, such as Abramovich and Shelton's (2017) book on homelessness, or Ball's (2016) take on criminology, Puar (2017) and others have taken this queering to gay spaces as well. In doing so, they provide insightful critiques of the norms extant in much lesbian and gay discourse; for example, Puar's (2017) critique of the "It Gets Better Project", or Johnson's (2001) coining of “quare". These queerings are some of the more fricative spaces of queer theory, causing sparks, chafing, and stimulation. I claim, based upon my knowledge of CYC literature, that queer analytics has been only minimally applied in CYC. There is certainly a body of literature that looks at programming and "issues" related to LGBT youth (Bochenek, 2002; Fox, 2015; Moore \& Moore, 2000; Wagaman, 2015); however, much of this hews to inclusive space or normative psychology paradigms, not dissimilar to the Abramovich and Shelton (2017) quote above.

According to Ahmed (2006), the word "queer" has its origins in a word meaning "oblique" or "off line": "The lines we follow might also function as forms of 'alignment', or as ways of being in line with others. We might say that we are orientated when we are in line." (p. 15). Much CYC work seeks a relationship — a coming together or an alignment. As Ahmed (2006) pointed out, however, to get in line is to be disciplined. The orientation of many CYC services is an orientation of alignment. Young people are required to get in line or else risk being refused service - taken "off-program". This is an orientation of discipline. CYC as a relational practice based upon alignment merits queering. What is really being enacted through the therapeutic use of relationship, for example? How might "use of self" lead to a denial of others? When we seek to align with children, youth, and families, is the agenda actually to bring children, youth, and families into line? 
We do see glimpses of oblique queering. For example, de Finney et al. (2011) went a little out of line when they suggested "conceptualiz[ing] residential care as a site for radical advocacy and social change" (p. 361). de Finney et al. (2011) focused on the orienting and disciplining logic of residential placements as the place of analysis, rather than the genders or sexual orientations of those who enter the residence. By doing this, they looked at institutional manifestations of this logic upon bodies entering residential placement, which they saw as based on "a deep-seated belief that nonconforming gender expressions are something to be corrected" (p. 374). In their queering, there is a shift in focus from the trans body of the resident being the "problem" to the institution being the site in need of intervention.

While there has been a minimal application of queer theory in $\mathrm{CYC}$, there are examples of queer theory being developed in meaningful ways as it relates to children and youth. McCready (2013) used a "queer of color analysis (QOCA) ... as a form of critique designed to unsettle the dominant discourses, key questions and normative beliefs ..." (p. 512). According to Brockenbrough (2013), QOCA is based upon "queer of color epistemologies - or ways of knowing rooted in queer of color political struggles, cultural traditions, and lived experiences as lenses for knowledge production" (p. 427). These lenses use a historically situated sociocultural awareness to focus on specific issues affecting particular populations, which, in the case of McCready (2013), is Black queer male youth living in Toronto.

Shotwell (2016) argued that rather than identifying "bad" normativity and replacing it with the "good", one can look towards "open normativity" which "names those normativities that prioritize flourishing and tend toward proliferation, not merely replacing one norm with another" (p. 155). One of the open normativities QOCA points to is the adaptability of queer analytics. Its focus can be adjusted to examine particular inquiry contexts and agendas. One example is my ongoing doctoral inquiry with CYCPs from Care (CYCPfC), in which I wonder whether there might be a CYCPfC epistemology based upon "political struggles, cultural traditions, and lived experiences — as lenses for knowledge production" from those who lived "in care".

After presenting this paper at the conference, I was asked during the question and answer period how I defined "queer". This was linked to what the questioner perceived as the erasing of sexuality within my queering of CYC. The question requires an accounting regarding what makes something queer and asks if queer theory can be applied outside of contexts related to sexuality or gender. For example, why apply queer theory to care, CYC as a whole, or, as in my doctoral inquiry, CYCPfC? Why not focus on LGBTQI2SA children, youth, families, and CYCPs? There is nothing necessarily queer, in terms of sex, sexuality, or gender, when it comes to those with whom CYCPs work or those who have lived in the care of the state. So why is it necessary to queer care? Sedgwick (1993) defined queer as "the open mesh of possibilities, gaps, overlaps, dissonances and resonances, lapses and excesses of meaning when the constituent elements of anyone's gender, of anyone's sexuality, aren't made (or can't be made) to signify monolithically" (p. 8). One can argue that the project of state residential care is a project of monolithic intent. While I do not suggest this intent is primarily focused on sexuality or gender, I think queering 
provides insights into what intents do exist in residential care and CYC. Building on Sedgwick, one might ask whether thinking about sexuality and gender in care reveals meanings and intents of that segment of CYC practice.

A foundation of state care is the restriction of youth agency, including in the domain of sexuality. This is embedded in the language of social services. For example, child welfare agencies in the United States, Canada, and Europe are frequently called child protection services (or systems). Child protection is a notion that has come under many critiques, for a variety of reasons (International Institute for Child Rights and Development, n.d.; Dugmore, 2013), not least of which is how protection relates to sexuality (Egan \& Hawkes, 2009). These restrictions are supported by an extensive medico-judicial apparatus which has a long history of pathologizing and criminalizing activities outside of socially constructed acceptable child and youth sexuality (Foucault, 1978).

Conceptualizing childhood sexuality within the discourse of protection creates a framework that pathologizes the sexual subjectivity of children.... Within these narratives, once the sexual consciousness of the child is spurred into expression it is constructed as dangerous and pathological and thus in need of outside intervention (Egan \& Hawkes, 2009, p. 392).

A full discussion of child and youth sexuality and desire is beyond the scope of this article; however, it is pertinent to recognize that the state responds to young peoples' sexuality with sanctions, prohibitions, and pathologizing. This is all the more so when desire is queer - out of line - which, arguably, includes all child and youth desire according to the logic of child protection. This can be seen in the monolithic response to expressions and actions of desire from those in care.

To answer the question of how I am using "queer", it is, and yet is not only, about sexuality, gender, desire, and identity. I seek to apply queer analytics to all areas of CYC practice. Queer theory comes out of queer lives, but it need not be restricted to queer people. Through queering, I desire to honour the particularity of the critical thinking that these ways of being can lead towards in CYC. If we limit queer theory to considering only queer lives, we risk foreclosing what may be revealed. My intention is to try to queer identity, sexuality, desire, theory, and politics as an approach to CYC - as a way of caring for children, youth, families, and communities. I choose not to take a reductionist stance, but to play within "the open mesh of possibilities, gaps, overlaps, dissonances and resonances, lapses and excesses of meaning" (Sedgwick, 1993, p. 8).

Queer theory frequently takes into account experience, subjectivity, epistemology, power, and knowledge, which are all useful in understanding care. Many LGBTQI2SA young people come into various child and youth social service systems (Abramovich \& Shelton, 2017; de Finney et al., 2011). Developing queer critiques, as opposed to the more traditional liberal homonormative lesbian/gay studies approach to working with LGBTQI2SA folks, may serve this population better. 
International Journal of Child, Youth and Family Studies (2020) 11(2): 61-81

I stress "may". This position is part of the contested queer theory terrain mentioned above. Queer theory can be seen as a critical response to the politic of acceptability (Ball, 2016). This politic is evident in calls for gay, lesbian, and transgender people to be "allowed into" the military, and for same-sex couples to be able to be legally married.

What does the politic of acceptability look like within CYC? It reveals itself in rainbow flags and pink triangles mounted around homeless shelters, in Children's Aid pride brunches, and in field trips to see the movie Love Simon. It includes pink shirt anti-bullying campaigns that claim "all children are the same", "it doesn't matter who you love", and "sex is between the legs, gender between the ears". It may even bypass all discussion of gayness; for example, by reducing pink shirt day to a politically neutered "anti-bullying" event, as happened in multiple schools across Ontario in 2019. It shows up in LGBTQI2SAA, where the second A denotes "ally"; in implementing "zero tolerance programs"; and in claiming — if not insisting — that same-sex couples are just like everyone else, implicitly negating the existence of more than two genders. The heteronormative politic of acceptability is, paradoxically, a logic of homonormativity. Through acceptance calls, differences are elided in a formation of sameness. Thus, we see an embracing of that which is of "us", and a deepening resistance to that which is not. We see calls to, and demands for, alignment. Through a politic of acceptability, care risks becoming contingent upon alignment. This homonormativity is less about queering CYC, and more about quieting queerness.

\section{Care}

I recently did a presentation titled "If CY(C)". This title was an attempt to show the absence of care within CYC. This absence occurs in our theorizing, in our education, and, at times, even in our name: in Ontario, practitioners used to be designated "child and youth worker", not "CYC practitioner". Care is also too frequently absent in our institutional practice. This has been articulated, documented, and discussed by de Finney et al. (2018), Charles and Gabor (2006), and Gharabaghi et al. (2016), among others. In surveying CYC writing, there is remarkably little theory that is directly about care (Thomson, 2018). While the word "care" is everywhere in our publications, the actual deep thinking — theorizing, conceptualizing, and grappling — is minimal. However, this has not been my experience of conversations with practitioners, many of whom think profoundly about, and act with, care in their individual practices, practices that at times actively resist the lack of care in institutional practice.

CYC presents itself primarily as practice-based, with a literature that clearly situates CYC as a way of doing, "in direct work with children, youth, families and those who support them" (Garfat \& Fulcher, 2011, p. 1). Anglin (2001) wrote of five characteristics that differentiate CYC from other helping professions, stating that it:

- is primarily focussed on ... growth and development ...

- is concerned with the totality of a child's functioning ... 
International Journal of Child, Youth and Family Studies (2020) 11(2): 61-81

- has developed a model of social competence rather than a pathology-based orientation to child development ...

- is based on ... direct day to day work with children and youth in their environment, and

- involves the development of therapeutic relationships. (para. 4-8)

In these characteristics, there is a clear agenda and purpose to the caring within CYC. Garfat and Fulcher (2011) expanded the list of characteristics to 25 items, and ended their list by writing:

A Child and Youth Care approach may find ready applications in direct care work with people of all ages.... The Child and Youth Care approach represents a way of being and working in the world. It is, therefore, about how one does what they do. (p. 16)

CYC has long seen itself as a field that is about doing, being with, and working in "the life-space", and is based upon "moments" in the "co-created space" between CYCP and a child, youth, or family member (Garfat \& Fulcher, 2011).

Within this focus on "how one does what they do" it has been noted that written theory has at times been perceived as extraneous or unnecessary to CYC practice (Little, 2011). Thomson (2018) argued that there has been, and continues to be, a lack of theorizing about care in particular. Given that the field prominently situates care within its name, it is perhaps surprising that there has not been more writing on conceptualizations of care. "The Core of Care", by Maier (1979), was one of the earliest articles in this area. Maier named seven elements as comprising the core of care: bodily comfort, differentiations, rhythmic interactions, predictability, dependability, personalized behavioral training, and care for the care givers (pp. 162-172). Drawing directly from developmental psychology and observations from his work with children, he located care as developmental, ecological, and practice-based. This fits comfortably within the traditional paradigms that CYC has emerged from, and it would be easy to imagine Maier's piece being written today.

Maier (1979) starts by asking the reader to "pause and think of an incident where you experienced nurturing care. This would be a moment in your life when you had the sense of being the one, and only one, who counted at that particular moment" (p. 161). The heuristics of inductive analysis and of self-reflection are familiar approaches in considering care. Indeed, the self has been claimed as essential to "care ethics", as the practice of care "builds on the motivation to care for those who are dependent and vulnerable, and it is inspired by both memories of being cared for and the idealizations of self" (Sander-Staudt, n.d.). Maier's construction of care as being tied to affect, belonging, and recognizing differences in individuals (both receivers of care and "workers") 
is one that informs and is challenged by his own elements of care ${ }^{1}$. Care is relational and interdependent: the care "giver" is essential to the care "receiver" and by extension the receiver is essential to the giver. The child, youth, and family provide the opportunity to care. Drawing from moral, justice, virtue, and feminist theory (Held, 2006), along with, more recently, new materialism (Puig de la Bellacasa, 2017), care ethics can be seen to be as much aspirational as practised, what we might think of as "care desire". Held (2006) explained:

Caring well should be a moral goal, and basic caring relations are a moral necessity. The values involved in the practices of caring need to be understood and cultivated, and the failures of many practices to reflect these values also need to be understood. Caring as an actual practice should be continually evaluated and improved. To bring about such improvement radical transformations may be needed in the social and political contexts in which caring takes place. (p. 61)

Acts of care take place within social and political contexts. How these acts are performed reveals much about the contexts in which the acts of care, including $\mathrm{CYC}$, are embedded. Politics is an aspect of care that has always existed, although it has not always been recognized or named as such, particularly within CYC (Charles \& Gabor, 2006). Thomson (2018), tracing the construction of care within $\mathrm{CYC}$, argued, "CYC professed to approach care in an apolitical way focusing primarily on the one-on-one care relationship between worker-client, everyday caring interactions in a young peoples' [sic] life space and a utilitarian approach to care practices (Anglin, 1987)." (p. 23). Her use of "professed" is significant, for care ethics argues that care is not apolitical. The seven elements that Maier (1979) ascribed to the "core of care" can be read as instrumental, utilitarian, and apolitical, or one can recognize the overt political stance he made in his writings about "private space", which he proclaimed "is theirs [the child's] regardless of whether their behavior has been acceptable or not. Their personal (private) corner, bed, or other 'mine only' place is undisputedly theirs as part of their inalienable rights within the child care arena" (p. 163). Therefore, private space is less about the utilitarian notion of the "greatest good" or an instrumental means to an end, than it is about a single child and what might be best for them, regardless of the desires of the CYCP or the smooth functioning of the "home". As anyone who has lived or worked in residential care knows, this is indeed a radically political stance, and a moral stance as well. It is also a stance that is frequently violated.

Political, ethical, and theoretical elements of care do appear in some CYC writing, from Ricks' (1992) explicitly feminist reading of care in CYC, Smith's (2006) considerations of love as it relates to care, Newbury's (2014) discussion on the economics of care, and Thomson's (2018) "tracing" of how care is constructed in an introductory CYC text. Thomson's analysis of the

\footnotetext{
${ }^{1}$ Maier's (1979) seven elements are bodily comfort, differentiations, rhythmic interactions, the element of predictability, dependability, personalized behavioural training, and care for the caregivers (pp. 162-172).
} 
International Journal of Child, Youth and Family Studies (2020) 11(2): 61-81

presentation of care in Carol Stuart's 2013 textbook Foundations of Child and Youth Care Practice is worth quoting at length as it speaks directly to many of the ideas raised above:

Conceptualizations of care in the text are deeply influenced by normative frameworks such as neoliberalism and dominant conceptualizations of the self as individual, separate, and autonomous....

One of the main findings suggests that potentially there is a taken for granted understanding of care that is based on notions of care as apolitical, simple and practical....

There is a tendency in the text to frame care positively, which is demonstrative of an underlying assumption that all care is good. The consequence of this is that the text does not attend deeply to the complicated realities of the care relationship....

Further, my analysis suggests that the ability to care and care well as a CYC practitioner is understood in the textbook as being the result of an inherent personal quality and motivation. This reinforces essentialist discourses about care in CYC. (p. 96)

These findings extend beyond the Stuart text. Much writing regarding care within CYC is utilitarian, instrumental, and imbued with a masculinist-maternal essence, existing in a space neither/both paternal and maternal, patriarchal and feminist, indoctrinary and emancipatory.

What do I mean by the above claim?

Charles and Gabor (2006) categorized Canadian institutional residential care into five eras:

- Moralistic-Saviour: an 18th century agenda of "saving the souls of the young people";

- Reformation-Rescue: a shift away from souls and towards protecting children from "the abuses of the adult dominated world";

- Protection-Segregation: introduction of the first residential schools for Indigenous children;

- Treatment-Intervention: the beginning of psychiatric treatment for children and youth, as well as the rise of juvenile detention facilities; and

- Consumer-Community Partnership: the emergence in the 1970s of outpatient as well as community-based treatment programs, which continues to this day. (pp. 18-22)

These foundations are the ground upon which some approaches to CYC grew. Not the only ones, as I will discuss shortly; however, this history continues to inform our practice. As de Finney et al. (2018) wrote, CYCPs continue to be implicated in "transcarceral care systems": 
International Journal of Child, Youth and Family Studies (2020) 11(2): 61-81

In the public imagination, residential schools are part of a flawed ideological history we can now heal through reconciliation. But in fact, thousands of Indigenous and racialized children continue to be systematically detained, incarcerated, criminalized, institutionalized, and lost by US and Canadian authorities. For example, per capita, there are more Indigenous children in government "care" today than at any other point in history (Truth and Reconciliation Commission of Canada, 2015). We are in the midst of the "millennial scoop," a wave of government incarceration of Indigenous children, who represent less than $7 \%$ of the population, yet make up 48\% of children in government care (Turner, 2016)". (pp. 28-29)

Transcarceral care system involvement (what might be thought of as "in-care-ceration") is not unique to Indigenous children. As de Finney et al. (2018) pointed out, transcarceral care system involvement also disproportionately affects Black children and youth. In Ontario, due to a lack of race-based data tracking at many of the children's aid societies, it is hard to find exact numbers; however, a 2018 report from the Ontario Human Rights Commission "observed disproportionately high incidences of Indigenous and Black children in admissions into care at many [child welfare] agencies across the province" (Ontario Human Rights Commission, 2018, p. 2) The report states that, "Overall, the proportion of Black children admitted into care was 2.2 times higher than their proportion in the child population" (p. 4).

In considering transhistorical transcarceral in-care-ceration, some of the common elements that run through Charles and Gabor's (2006) five eras become apparent. What Shotwell (2016) called "purism" - an attempt to cleanse - resides in the religious imperative of the moralistic-saviour era towards "saving the souls of young people" (Charles \& Gabor, 2006, p. 18); in the milieu focus (reformation-rescue era) and treatment focus (treatment-intervention era) as applied to particular demographics; and in the removal of Indigenous and racialized bodies (protection-segregation era). Essential to this agenda remains the perception that the young person, their family, or their culture needs to change due to some impurity, and it is the duty of service providers to ensure that the young person, the family, and the culture align with that period's purism. CYC as a practice of intervening, categorizing, saving, containing, fixing, and purifying is a particular understanding of CYC that comes out of residential care, one that is patriarchal, colonialist, and curative. This framing of CYC is akin to what Fusco (2016) has called the "sociology of regulation", which she contrasted with the "sociology of change" in youth work.

According to Fusco (2016), a sociology of regulation focuses on changing the young person. It incorporates character building, treatment, social education, and youth development agendas, all of which mesh neatly with Charles and Gabor's (2006) five eras. A sociology of change, in contrast, focuses on the young person doing the changing. Rooted in radical humanism and structuralism, it incorporates empowerment discourses, youth leadership, organizing, and civic engagement. The relationship between these different approaches can be seen in some of the current tensions within CYC. 
In examining the histories of adults working with young people, we can ask who is being cared for and what is being cared about. Caring is not neutral. Along with noble-sounding aims - saving the soul, saving the psyche, saving the child - the history of "caring" includes forced medication, incarceration, sterilization, and eugenics (Chapman \& Withers, 2019; Clare, 2017). Grappling with care requires acknowledging this legacy and understanding its effects on CYC.

But these are not the only histories. There is a history of care rooted in relationship, not removal, such as how children were cared for in precolonial times (as mentioned by Beukes and Gannon [n.d.] in their look at CYC practice in what is now known as South Africa). There is a history of care that is feminist, ethical, and loving (Held, 2006; Sander-Staudt, n.d.). It concerns affect and politics. It is personal, social, and transformative. It is this history that has brought some of us into the caring fields. It is a history of communities looking out for each other, and friends and family supporting those in need. Mothers, fathers, aunties, siblings, neighbours, and strangers caring for and caring with.

In the May 2019 episode of the CYC podcast ${ }^{2}$, I interviewed Juanita Stephen and Peter Amponsah about the CYC Alliance for Racial Equity (CARE). Stephen spoke about diverse theories of care that come out of Black communities, theories that I've never seen referenced in my CYC care readings. Amponsah spoke about intergenerational continuums of care that the carer brings - care rooted in historical practices, and transgenerational care ethics that have been passed down from one generation to the next. As seen from the texts above, this transgenerational care legacy can be transcarceral (de Finney et al. 2018), or it can be transformative (Beukes \& Gannon, n.d.). Graham (2007) considered a Black feminist ethics of care in order to "open up new insights into care and its multiple dimensions" (p. 194). Graham (2007) wrote of the interdependency of care that simultaneously resists and fosters:

From an African-centred perspective, ethics are employed in the practical outworking of personhood and the freedom to develop fully one's human dispositions through interaction with others. Interdependence offers a condition of existence and moral capacity which is held together by relationships and human connections.... Self-determination and freedom have long been a site of resistance and empowerment in everyday action and experience. (p. 200)

Interdependence, resistance, relationality, ethics, action, and experience: all of these are elements that fit within CYC theory and practice. As Steckley and Smith (2011) wrote, care is interdependent, reciprocal, dialogic, fallible, and flexible. Tronto (2015) reminded us that care is relational: to care for asks that we are responsible (p. 5), to care about that we are attentive (p. 5), and to care give that we are adept (p. 6); listening to those who care receive makes us responsive (p. 6). Caring is a political act. It is a relational act. It is a transformative act. Yet it is not only an

\footnotetext{
${ }^{2}$ http://www.cycpodcast.org/
} 
International Journal of Child, Youth and Family Studies (2020) 11(2): 61-81

act. It is also a disposition, as Smith (2019) pointed out. Care is not exclusively what we do, it is also why and how we do it. As Berry et al. (2018) wrote:

In a time of late capitalism, the ethics of care in child and youth care work can no longer be viewed as a purely individual, human pursuit. Extracted from its relational origins and appropriated as a tool for managing and regulating bodies, care within contemporary global capitalist structures is located as an isolated, moral choice. This conceptualization of care ignores the socio-political constellations which frame 'free' choice. Sole responsibility of ethical work is placed in the bodies of individuals amid systemic discourses of production and progress which instrumentalize care and perpetuate oppressive conditions to which CYC work aims to respond. (p. 49)

\section{Queering Child and Youth Care}

What then does queering care in CYC do? Consider the multiple ways that "queer" has been taken up - desire, identity, sexuality, theory, and politics. Each provides opportunities to queer CYC. As a preliminary conceptualization of how these five facets of queering may be relevant, I will give an example of each, applying them to practice, theory, or inquiry. There are multiple other ways these five facets could be taken up. I provide the following only as initial flirtations.

\section{Desire}

Desire as an operating function of CYC opens possibilities regarding ways of being, being with, and becoming. Rather than beginning with the deconstruction or contestation of queering, desire leads us to the imaginative "if", to finding ways of practising, theorizing, teaching, and researching that are about what we, and those we work with, desire - what is sought, what is fantasized, what motivates. The possibilities of desire lead toward a politics of pleasure, a perhaps radical way of considering engagement with our colleagues, those we work with, how we research, and why we do CYC. Enjoyment, pleasure, and desire as criteria in considering CYC practice may not be regarded as relevant by all; indeed, it may be seen as part of the problem. However, new possibilities arise when we introduce these conditions for consideration. Quoting Peter Reason, Foster (2016) wrote, "If human inquiry is not exciting, life enhancing, even pleasurable, then what is it worth?" (p. 134). This I suggest is also true of CYC outside of inquiry alone. Pleasure becomes a political and ethical stance when working with people and imagining what their futures hold.

\section{Identity}

Identity within CYC is a contested space (Vachon, 2013). The arguments about what is and is not CYC, who is and is not a CYCP, if CYC is or is not a profession, a field, or a way of being, continue to arise in conferences, faculty discussions, multidisciplinary team meetings, and informal conversations. Generally, the young people I work with have no idea of my professional or academic credentials. Labels like CYCP, social worker, psychologist, counsellor, and 
practitioner mean little to most people I engage with. While titles may hold value for professionalization, accreditation, employment, salary, and membership in one organization or another, I suspect they hold minimal value for those seeking services (except when needed to satisfy the requirements of insurance, payments, funding, and the like). CYC identity does matter in that it creates a sense of belonging and a way of orienting practice, and provides a body of literature and a language to discuss that literature. I do call myself a CYCP. Yet, identity risks becoming restrictive, creating hierarchies, and being dismissive of alternative ways of thinking, working, practising, and being. One of the ironies of queer identity is the pull to rigidity. Rather than being deconstructive, queer identity at times becomes constrictive. Who is or is not queer? Is queerness about the people one loves, those one sleeps with, a sense of self, or whom one watches in porn? Does queer need to be about sex, about desire, about identity, about a political position? Is it, like care, both a disposition and an action? What makes one queer enough to justify applying the appellation? Lost in the constrictive defining are some of the very things queer does, such as revealing "the open mesh of possibilities, gaps, overlaps, dissonances and resonances, lapses and excesses of meaning" (Sedgwick, 1993, p. 8). I worry that this is also true of CYC. While I value my identity as a CYCP, it does at times seem over-policed regarding what ideas I draw upon, who I cite, the way I practise, and if my way of working is legitimate. How queer is queer enough?

\section{Sexuality}

Acts of sexuality within CYC are perhaps the most, and least, comfortable of the queer framings I draw upon. There is a body of literature within CYC that addresses practice with LGBQI2SA young people - identified, of course, by their sexuality. Much of this, as AndersonNathe (2019) pointed out during his presentation at the UVic conference, is rooted in the language of LGBQ "issues", "challenges", and other pathologizing framings. As noted by Abramovich and Shelton (2017) and de Finney et al. (2011), many LGBTQI2SA people access CYC services and need resources to support them in ways that reflect and honour who they are, including their sexuality, gender, identity, needs, and desires. There are few, if any, CYCPs who would disagree with this position. While there may be disagreement on what care with LGBTQI2SA people looks like, all would likely agree that support ought to be available to those who require it.

However, it is a rare residential program that goes beyond asexual support of queer children and youth (or, indeed, most children and youth). There are few group homes or shelters that allow young people to have sex on the premises, regardless of sexual orientation or whom they are having sex with. Such a policy seems contradictory when we claim that we want to reduce harm - risk of exploitation, abuse, and STIs. Within a residential setting, help would potentially be available from caring supportive adults who are on the premises if one of the young people perceives a need for support in dealing with an issue like discomfort, violence, STI protection, or emotional upset after sex. Having sex in parks, cars, alleys, stairwells, garages, toilets, squats, motels, bushes and other locations poses additional safety risks for young people. While the rationales abound, I can think of few legitimate reasons as to why young people should not be allowed to have sex in their group homes, shelters, foster homes, or other living spaces; we know full well that young people 
are having sex in all of these places, most frequently without the permission of the adults present, and at times risking sanctions, expulsion, or homelessness in doing so. Sharing our own sexual experiences, how we learned what gives us sexual pleasure, and techniques or approaches to sexuality are all elements to consider in queering sexuality within CYC.

\section{Theory}

An analysis grounded in "an active process of contesting scholarship and politics, contesting categories, contesting identity, contesting liberalism, contesting truth, contesting history, and contesting subjectivity" while simultaneously "expounding, elaborating, and promoting alternative ways of being, knowing, and narrating experience" (Alexander, 2018, p. 278) is a good start towards queering CYC. We can also draw on QOCA "as a form of critique designed to unsettle the dominant discourses, key questions and normative beliefs" (McCready, 2013, p. 512) that exist within our field, a field whose writing, education, and management is dominated by White heterosexuals. Ball's (2016) understanding that "queering something involves a deconstructive disposition that points to norms, resists them, and opens up a space in which things might be done differently" (p. 35) provides useful frames for us to draw upon. Care within CYC merits all of these approaches. Understanding how "care" has been used as a way to oppress young people, families, and particular communities, while normalizing these oppressions, forces CYC to reflect upon our complacency at one end and active perpetuation of harm at the other. Through particular historical lenses of CYC practice, the notion of interdependency starts to seem more parasitic than symbiotic. Queering CYC requires looking at the implications of "caring", considering how it fosters and how it resists, in all its many helpful and destructive ways.

\section{Politics}

Political and apolitical framings of CYC have been present for many years now, as Thomson (2018) pointed out. In Canada, we increasingly see politics productively forced onto the agenda at conferences, in hiring, in curriculum, and in the ways that CYCPs work with young people. We have seen a growing tension between "development" and "social justice" approaches to CYC practice, and, more recently, a reckoning regarding racism within CYC (Daniels, 2018; Gharabaghi, 2017; Vachon, 2018). In the debates around these framings we see echoes of homonormative and queer politics. Resistance to the homogenizing politics of homonormativity can be loudly heard in the "queercore"3 phrase "not gay as in happy but queer as in fuck you" (Nault, 2018, p. 5). I am not suggesting that this be the opening gambit in queering CYC. I am

\footnotetext{
${ }^{3}$ Nault (2018) glosses queercore as “a configuration of artistically minded gender/sexual dissidents who annex punk practices and aesthetics to challenge the oppressions of the mainstream and the lifeless sexual politics and assimilationist tendencies of dominant gay and lesbian society. This subculture is known as 'homocore' or, more recently, 'queercore', to indicate an alliance with antiestablishment radical queer politics — as opposed to a liberal gay politics of social integration. 'Queercore' invokes a movement that is by and for not only homosexuals, but genderqueers, transgender folks and all those whose gender and/or sexual identities fall outside restrictive male/female, heterosexual/homosexual binaries." (p. 1).
} 
International Journal of Child, Youth and Family Studies (2020) 11(2): 61-81

suggesting we listen to every "fuck you" and strive to hear the invitation to open the space in which things can be done differently.

\section{References}

Abramovich, A., \& Shelton, J. (Eds.). (2017). Where am I going to go? Intersectional approaches to ending LGBTQ2S youth homelessness in Canada \& the U.S. Canadian Observatory on Homelessness Press.

Ahmed, S. (2006). Queer phenomenology. Duke University Press.

Alexander, B. K. (2018). Queer/quare theory: Worldmaking and methodologies. In N. K. Denzin and Y. S. Lincoln (Eds.), The SAGE handbook of qualitative research (5th ed., pp. 275-307). Sage.

Anderson-Nathe, B. (2019, April 25-27). Queer young people's coming of age experiences [Paper presentation]. Child \& Youth Care in Action VI Conference, University of Victoria, Victoria, British Columbia.

Anglin, J. (2001). Child and youth care: A unique profession. CYC-Online, 35. Retrieved from http://www.cyc-net.org/cyc-online/cycol-1201-anglin.html

Ball, M. (2016). Criminology and queer theory: Dangerous bedfellows? Palgrave Macmillan. doi:10.1057/978-1-137-45328-0

Berry, A., Do Nascimento, A., \& Pacini-Ketchabaw, V. (2018). Pedagogies of care: Thinkingwith and paying attention. CYC-Online, 235, 49-57. Retrieved from https://www.cycnet.org/cyc-online/sep2018.pdf

Beukes, K., \& Gannon, B. (1999). A history of child and youth care in South Africa. From K. Beukes \& B. Gannon, An orientation to child and youth care $\left(2^{\text {nd }}\right.$ ed.). National Association of Child Care Workers. Retrieved from http://www.cyc-net.org/reference/refs-history $\underline{\text { beukesgannon.html }}$

Bochenek, M. (2002). School practitioners supporting LGBTQ students. CYC-Online, 15(3), 6980. Retrieved from https://www.cyc-net.org/cyc-online/cycol-0206-bochenek.html

Brockenbrough, E. (2013). Introduction to the special issue: Queers of color and anti-oppressive knowledge production. Curriculum Inquiry 43(4), 426-440. doi:10.1111/curi.12023

Chapman, C., \& Withers, A. J. (2019). A violent history of benevolence: Interlocking oppression in the moral economies of social working. University of Toronto Press. 
International Journal of Child, Youth and Family Studies (2020) 11(2): 61-81

Charles, G., \& Gabor, P. (2006). An historical perspective on residential services for troubled and troubling youth in Canada revisited. Relational Child and Youth Care Practice. 19(4), $17-26$.

Clare, E. (2017). Brilliant imperfection: Grappling with cure. Duke University Press

Daniels, B.-J. (2018). Racism is a thing! Re-examination of the concepts of care and relational practice in the preparation of child and youth care practitioners. Relational Child and Youth Care Practice, 31(3), 31-42.

de Finney, S., Dean, M., Loiselle, E., \& Saraceno, J. (2011). All children are equal, but some are more equal than others: Minoritization, structural inequities, and social justice praxis in residential care. International Journal of Child, Youth and Family Studies, 2(3/4), 361-384. doi:10.18357/ijcyfs23/420117756

de Finney, S., Palacios, L., Mucina, M. K., \& Chadwick, A. (2018). Refusing band-aids: Unsettling "care" under the carceral settler state. CYC-Online, 235, 28-38. Retrieved from https://www.cyc-net.org/cyc-online/sep2018.pdf

Dugmore, P. (2013). Working together, or keeping apart? A critical discourse analysis of the revised working together guidance (2013). Journal of Social Work Practice, 28(3), 329-341. doi:10.1080/02650533.2014.925863

Egan, R. D., \& Hawkes, G. (2009). The problem with protection: Or, why we need to move towards recognition and the sexual agency of children. Continuum: Journal of Media \& Cultural Studies, 23(3), 389-400. doi:10.1080/10304310902842975

Foster, V. (2016). Collaborative arts-based research for social justice. Routledge.

Foucault, M. (1978). The history of sexuality: Volume 1: An introduction. Pantheon.

Fox, L. E. (2015). Exploring sexual diversity: Helping children and young people develop understanding and respect for differences in the human family. CYC-Online, 191, 8-16. Retrieved from https://www.cyc-net.org/cyc-online/dec2014.pdf

Fusco, D. (2016). History of youth work: Transitions, illuminations, and refractions. In M. Heathfield \& D. Fusco (Eds.), Youth and inequality in education: Global actions in youth work. Routledge.

Garfat, T., \& Fulcher, L. (2011). Characteristics of a child and youth care approach. Relational Child and Youth Care Practice, 24(1-2), 7-19.

Gharabaghi, K. (2017). Why are we so white? CYC On-Line, 220, 6-10. Retrieved from https://www.cyc-net.org/cyc-online/jun2017.pdf 
International Journal of Child, Youth and Family Studies (2020) 11(2): 61-81

Gharabaghi, K., Trocmé, N., \& Newman, D. (2016). Because young people matter: Report of the Residential Services Review Panel. Retrieved from http://www.children.gov.on.ca/htdocs/English/documents/childrensaid/residential-servicesreview-panel-report-feb2016.pdf

Graham, M. (2007). The ethics of care, Black women and the social professions: Implications of a new analysis. Ethics and Social Welfare, 1(2), 194-206. doi:10.1080/17496530701450372

Held, V. (2006). The ethics of care: Personal, political, and global. Oxford University Press.

International Institute for Child Rights and Development. (n.d.). Search: "residential” (Website). http://www.iicrd.org/search/node/residential

Johnson, E. P. (2001).Quare studies, or (almost) everything I know about queer studies I learned from my grandmother. Text and Performance Quarterly, 21(1), 1-25. doi: $10.1080 / 10462930128119$

Little, J. N. (2011). Articulating a child and youth care philosophy: Beyond binary concepts. In A. Pence \& J. White (Eds.), Child and youth care: Critical perspectives on pedagogy, practice and policy (pp. 3-18). UBC Press.

Maier, H. (1979). The core of care: Essential ingredients for the development of children at home and away from home. Child Care Quarterly, 8(3), 161-173.

McCready, L. (2013). Conclusion to the special issue: Queer of color analysis: Interruptions and pedagogic possibilities. Curriculum Inquiry 43(4), 512-522. doi:10.1111/curi.12024

Mississaugas of the Credit First Nation. (n.d.). The Toronto Purchase Treaty No. 13 (1805). $\underline{\text { http://mncfn.ca/torontopurchase/ }}$

Moore, P., \& Moore, B. (2000). "Out” and "in": Homophobic issues in residential care. Journal of Child and Youth Care, 13(4), 29-34. Retrieved from https://www.cyc-net.org/cyconline/cyconline-feb2010-moore.html

Muñoz, J. E. (2009). Cruising utopia: The then and there of queer futurity. New York University Press.

National Inquiry into Missing and Murdered Indigenous Women and Girls. (2019). Reclaiming power and place: The final report of the National Inquiry into Missing and Murdered Indigenous Women and Girls. Retrieved from https:/www.mmiwg-ffada.ca/final-report/

Nault, C. (2018). Queercore: Queer punk media subculture. Routledge. 
International Journal of Child, Youth and Family Studies (2020) 11(2): 61-81

Newbury, J. (2014). Post-growth possibilities for child and youth care. In K. Gharabaghi, H. Skott-Myhre, \& M. Krueger (Eds.), With children and youth: Emerging theories and practices in child and youth care work (pp. 121-147). Wilfrid Laurier University Press.

Ontario Human Rights Commission. (2018). Interrupted childhoods: Over-representation of Indigenous and Black children in Ontario child welfare. Retrieved from http://www.ohrc.on.ca/en/interrupted-childhoods

Puar, J. K. (2017). The right to maim: Debility, capacity, disability. Duke University Press.

Puig de la Bellacasa, M. (2017). Matters of care: Speculative ethics in more than human worlds. University of Minnesota Press.

Ricks, F. (1992). A feminist's view of caring. Journal of Child and Youth Care, 7(2), 49-57.

Sander-Staudt, M. (n.d.). Care ethics. The Internet Encyclopedia of Philosophy. Retrieved December 18, 2018 from https://www.iep.utm.edu/care-eth/

Sedgwick, E. K. (1993). Tendencies. Duke University Press.

Shotwell, A. (2016). Against purity: Living ethically in compromised times. University of Minnesota Press.

Simpson, L. (2008). Looking after Gdoo-naaganinaa: Precolonial Nishnaabeg diplomatic and treaty relationships. Wicazo Sa Review, 23(2), 29-42. doi:10.1353/wic.0.0001

Smith, M. (2006). ss. Relational Child and Youth Care Practice, 19(4), 5-16.

Smith, M. (Interviewee). (2019, February 27). Care in child and youth care: A conversation with Dr. Mark Smith [Audio podcast]. Retrieved from http://www.cycpodcast.org/e/care-in-childand-youth-care-a-conversation-with-dr-mark-smith/

Steckley. L., \& Smith, M. (2011). Care ethics in residential child care: A different voice. Ethics and Social Welfare, 5(2), 181-195. doi:10.1080/17496535.2011.571068

Stephen, J., \& Amponsah, P. (Interviewees). (2019, May 29). A conversation with Juanita Stephen and Peter Amponsah from the Child and Youth Care Alliance for Racial Equity (CARE) [Audio podcast]. Retrieved from http://www.cycpodcast.org/e/a-conversation-withjuanita-stephen-and-peter-amponsah-from-the-child-and-youth-care-alliance-for-racial-equitycare-1559099304/ 
International Journal of Child, Youth and Family Studies (2020) 11(2): 61-81

The Truth and Reconciliation Commission of Canada. (2015). Honouring the truth, reconciling for the future: Summary of the final report of the Truth and Reconciliation Commission of Canada. Retrieved from http://www.trc.ca/assets/pdf/Honouring the Truth_Reconciling for the Future July 23 201 5.pdf

Thomson, J. (2018). Re-imagining care: Thinking with feminist ethics of care [Master's thesis]. University of Victoria, Victoria, British Columbia. Dspace.

https://dspace.library.uvic.ca/bitstream/handle/1828/9675/Thomson_Jenny_MA_2018.pdf?se quence $=1 \&$ isAllowed $=y$

Tronto, J. C. (2015). Who cares? How to reshape a democratic politics. Cornell University Press.

Turner, A. (2016). Living arrangements of Aboriginal children aged 14 and under. Statistics Canada. Retrieved from https://www150.statcan.gc.ca/n1/pub/75-006x/2016001/article/14547-eng.htm

Vachon, W. (2013). Do not enter: What are the risks of gatekeeping child and youth care? Child \& Youth Services, 34(2), 156-171. doi:10.1080/0145935X.2013.785888

Vachon, W. (2018). Child and Youth Care fragility. CYC-Online, 232, 14-18. Retrieved from https://www.cyc-net.org/cyc-online/june2018.pdf

Wagaman, M. A. (2015) Changing ourselves, changing the world: Assessing the value of participatory action research as an empowerment-based research and service approach with LGBTQ young people. Child \& Youth Services, 36(2), 124-149.

doi:10.1080/0145935X.2014.1001064 